\title{
The Optimization of Lead Electrodeposition from Leachant of Lead Laden Cupels
}

\author{
Innocencia S. Mpofu, Edwina Muleya, Washington Mutatu \\ Department of Chemical Technology, Midlands State University, Gweru, Zimbabwe \\ Email: mutatuw@gmail.com
}

Received 31 May 2016; accepted 23 July 2016; published 26 July 2016

Copyright (C) 2016 by authors and OALib.

This work is licensed under the Creative Commons Attribution International License (CC BY). http://creativecommons.org/licenses/by/4.0/

(c) †) Open Access

\begin{abstract}
Disposal of lead laden cupels is proving problematic to mining and metallurgical companies due to environmental and health issues. In this study the optimization of operation parameters for the electrode position of lead metal from acetic acid leachant was carried out. The effects of voltage, temperature, concentration, size of electrode and the effect of the space between the electrodes were investigated. Acetic acid (10\%) was used as a leachant in the optimization process. The optimum voltage was found to be $6 \mathrm{~V}$, with the best operating temperature of $20^{\circ} \mathrm{C}$. The amount of lead deposited increased with increase in concentration of the lead in solution up to an optimum concentration of $2271.1 \mathrm{ppm}$. However the extraction efficiencies tended to decrease with increase in concentration. The optimum inter-electrode distance was observed to be $4 \mathrm{~cm}$ with 0.5 $\mathrm{cm}$ radius electrodes that gave the largest extraction efficiency $(70.9 \%)$. Acetic acid $(10 \%)$ was preferred as a leachant compared to EDTA $(0.1 \mathrm{M})$ because it gave higher leaching and electrode position efficiencies $(73.3 \%$ vs 68.1$)$ and $(95 \%$ vs 90.8$)$ respectively. EDTA $(0.1 \mathrm{M})$ was however found to be less corrosive to the carbon electrodes as observed with acetic acid. Other advantages of acetic acid are that it is cheaper, can be obtained from renewable sources and is easy to use because there is no need for constant $\mathrm{pH}$ monitoring and adjustments.
\end{abstract}

\section{Keywords}

Cupel, Leaching, Leachant, Electrodeposition, Aceticacid, EDTA

Subject Areas: Electrochemistry

\section{Introduction}

Lead has been used since the ancient times [1]. It is an important non-ferrous metal that, because of its good chemical and physical properties is made use of in the electric, chemical engineering, construction and other industries [2]. In 20141.15 million tonnes of secondary lead was produced and it accounted for $70 \%$ of the lead 
consumption [3]. Zimbabwe has the second largest platinum deposits in the world, with the Great Dyke being the host of platinum and chromite resources. The lead fire assay method is the method of choice that is used for gold determination and for separation of PGM's and other precious metals into the lead metallic phase and the silicate phase [4] [5]. The process occurs as follows: a pulverized sample, containing the precious metals is weighed and mixed with a fluxing agent [6]. The resulting sample is then heated in a furnace where it fuses and separates from the "button" (collector material), which contains the precious metals. The lead is then separated from the precious metals by oxidation and absorption in the cupellation process [5] [6].

Cupellation is the treatment of the lead button, so as to separate the precious metals from lead [4] [7]. Lead is oxidized into molten litharge ( $\mathrm{PbO})$ [1] and absorbed into the cupel; the precious metals are not absorbed into the cupel because of their high surface tension and failure to be oxidized under the cupellation conditions [4]. According to Mangunda et al. [8], the waste cupels contain between $50 \%$ and $60 \% \mathrm{w} / \mathrm{w}$ lead.

The disposal of lead bearing cupels is a cause for major concern to the ecosystem. According to the Zimbabwean waste and solid waste disposal regulations SI No. 6 of 2007, disposal of waste into groundwater or public streams without a license is highly prohibited [9]. EMA is empowered to issue spot fines to anyone whose substance affects the environment; this is according to the hazardous substances, pesticide and toxic substances regulations, SI No. 2 of 2007 [9]. Over the years there has been a huge increase in the amount of lead bearing waste in the form of cupels, slag and fusion crucibles [5] with most companies burying the lead laden cupels in concrete lined pits and facing the challenge of a continual increase in the amount of the buried cupels over time.

The recovery of heavy metals is carried out for two major reasons: environmental protection and the economy. This study focused on the recycling of the lead from the lead laden cupels. Lead can be dissolved by chemical dissolution in acid electrolytes [10]. Recovery of lead from pulverized cupels into acetic acid was done; it was discovered that exhaustive extraction with five $100 \mathrm{ml}$ portions of $10 \%$ acetic acid with a $5 \mathrm{~g}$ sample at $250 \mathrm{rpm}$ and room temperature, gave a leaching efficiency of $98.97 \%$ [4]. The optimal temperature was at $27^{\circ} \mathrm{C}$ with optimal leaching time of 15 minutes which gave a lead recovery of 89.1\% [4].

Due to EDTA's strong complexing ability towards heavy metals it has been said to be an effective chemical for the extraction of lead from lead contaminated solids [11]. The $\mathrm{pH}$ of an EDTA solution determines the ionic species present in the system [11].

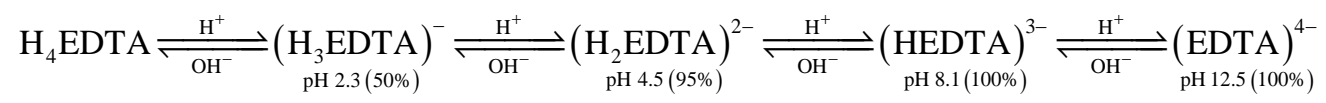

The reaction of EDTA with lead changes based on the solution $\mathrm{pH}$ [12]. Lead having a coordination number of six forms a very stable six coordinate complex, Pb-EDTA, as one of its more stable complexes [12]. EDTA is an effective complexing agent with lead as it has a Pb-EDTA stability constant, $\log K$, of 18.3 [12]. Electrical efficiency and the composition and morphology of electrodeposits significantly vary and depend on [13];

Current density [13]; where $I$ — current, $V$-voltage, $R$-resistance.

$$
I=V / R
$$

Temperature;

Space between electrodes;

Electrolyte quality [14], [15];

Size and alignment of electrodes [14];

Concentration;

Potential difference [16].

Acetic acid is corrosive and can cause burns when pure and concentrated with its flash point being at $39^{\circ} \mathrm{C}$ [17]. Corrosion of stainless steel and carbon steel by acetic acid is reported [18]. In this study the optimization of operation parameters for the electrodeposition of lead metal from acetic acid leachant was carried out. The effect of voltage, temperature, concentration, size of electrode and the effect of the space between the electrodes were investigated.

\section{Experimental Work}

\subsection{Extraction of Lead from Lead Laden Cupels}

A kilogram of lead laden cupels were pulverized to $<75 \mu$ m. Lead extractions were then carried out using 100 
$\mathrm{ml}$ of $10 \%$ acetic acid (Skylabs) on a $5 \mathrm{~g}$ sample of pulverized cupel at room temperature with shaking on a rotary shaker (Remi, Visai, India) at $250 \mathrm{rpm}$ for 30 minutes [4]. After leaching, vacuum filtration was done so as to obtain the lead acetate effluent for electrodeposition. Solution was stored in a polyethene bottle at room temperature.

\subsection{Effect of Voltage on the Extraction of Lead}

Solutions of $200 \mathrm{ml}$ were used at room temperature with a $4 \mathrm{~cm}$ inter-electrode distance. Electrodeposition of lead was carried out for an hour at different voltages ranging from 2 volts to 12 volts using a dc high voltage power supply (Philip Harris-Findel Limited, United Kingdom). Lead acetate (5 ml) samples were collected for the initial and final solution for analysis on the Flame Atomic Absorption Spectophotometer (Savant AA-GBS Scientific, Braeside, Australia). During the electrodeposition process lead metal was collected at 5 minutes intervals for drying and weighing so as to determine the effect of voltage on the amount of metal deposited. Final and initial cathode masses were weighed and graphs of mass of lead collected against time were plotted [15]. The extraction efficiencies were calculated using the formula shown below;

Electrodeposition extraction efficiency:

For $1^{\text {st }}$ run

$$
E_{1}=C_{\text {ini }}-C_{\text {fin }}
$$

where; $C_{\text {ini }}$ - concentration of lead in initial sample.

$C_{\text {fin }}$ - concentration of lead in final sample.

$\%$ extraction;

$$
\% E_{1}=E_{1} / C_{\text {ini }}
$$

For $2^{\text {nd }}$ run

$$
E_{2}=C_{2 \text { ini }}-C_{2 \text { fin }}
$$

\% extraction;

$$
\% E_{2}=E_{2} / C_{2 \text { ini }}
$$

Overall extraction efficiency

$$
\% E_{o}=\left(\frac{\% E_{1}+\% E_{1}}{2}\right) \times 100 .
$$

\subsection{Effect of Temperature on the Extraction of Lead}

By use of hot and cold water baths temperature was varied in the ranges $10^{\circ} \mathrm{C}-35^{\circ} \mathrm{C}$ at $6 \mathrm{~V}$ direct current with a $4 \mathrm{~cm}$ electrode distance on a $200 \mathrm{ml}$ solution for an hour.

\subsection{Effect of Concentration on Lead Extraction}

After the extraction of lead from lead laden cupels a solution of $2271.1 \mathrm{ppm}$ was obtained. This solution was further diluted into three other solutions using factors of $1 / 4,1 / 2$ and 3/4 giving solutions of $637.1 \mathrm{ppm}, 1147.1$ ppm and $1711.5 \mathrm{ppm}$ respectively. These solutions together with the $2271.1 \mathrm{ppm}$ solution were the ones used for the determination of concentration. Everything else was kept constant except for the solution concentrations which were varied from $637.1 \mathrm{ppm}$ to $2271.1 \mathrm{ppm}$. Electrodeposition for each concentration was carried out for 2 hours, at 5 minute batches, at $20^{\circ} \mathrm{C}$, at an electrode distance of $4 \mathrm{~cm}$ with a $6 \mathrm{~V}$ dc power supply [15] [16].

\subsection{Effect of the Size of the Carbon Electrode on Lead Extraction}

Extraction was carried out for an hour at a similar concentration, $20^{\circ} \mathrm{C}$ temperature, with a $4 \mathrm{~cm}$ distance between the anode and cathode, with a $6 \mathrm{~V}$ dc supply on $200 \mathrm{ml}$ solutions. The carbon electrodes used were cylindrical and of the same length, $12 \mathrm{~cm}$ and different radii (0.5 and $1 \mathrm{~cm}$ radii). 


\subsection{Effect of Distance between Electrodes on the Extraction of Lead}

The electrodeposition processes were carried out at $6 \mathrm{~V}, 20^{\circ} \mathrm{C}$, on $400 \mathrm{ml}$ solutions in a bigger container than the one that had been used for other processes. The distances between electrodes were varied from 1 to $7 \mathrm{~cm}$ electrode distance [15].

\subsection{Comparing the Effectiveness of Acetic Acid and EDTA on Leaching and Electrodeposition}

EDTA (Skylabs) was used to compare its extraction efficiencies with those of acetic acid. Leaching was done at $\mathrm{pH} 4$ on $5 \times 5$ g samples using $100 \mathrm{ml}$ of $0.1 \mathrm{M}$ solution portions on each extraction. $0.1 \mathrm{M} \mathrm{HCl}$ was used to adjust the $\mathrm{pH}$ of the solution [11]. A magnetic stirrer was used to stir the solution and maintain heat at $55^{\circ} \mathrm{C}$ for 24 hours. A $5 \mathrm{ml}$ solution sample was collected for analysis on the AA. Electrodeposition was then carried out at $25^{\circ} \mathrm{C}, 8 \mathrm{~V} \mathrm{dc}, 4 \mathrm{~cm}$ distance between electrodes, with a $0.5 \mathrm{~cm}$ radius carbon electrode on a $200 \mathrm{ml}$ solution for 2 hr 30 minutes [19].

Acetic acid leaching was carried out at room temperature with $10 \%$ acetic acid on $5 \times 5$ samples using $100 \mathrm{ml}$ sample portions [4]. Extraction was done for 30 minutes with shaking. A $5 \mathrm{ml}$ solution sample was collected for analysis on the AA. Electrodeposition process was carried out as with that of the EDTA solution [8]. Results obtained were compared and leaching extraction efficiencies calculated using the formula shown below;

Leaching extraction efficiency:

$$
([S] /[C]) \times 100
$$

where; $[S]$ — concentration of lead in leachate after leaching (ppm).

$[C]$ — concentration of lead in cupel before leaching (ppm).

\subsection{Analysis on the XRF}

A handheld XRF analyser (Delta Dynamic-OLYMPUS) was used to analyse samples of:

1) The pulverized cupel.

2) Lead metal extracted from the lead acetate electrodeposition process.

3) Lead metal extracted from the Pb-EDTA electrodeposition process.

\subsection{Analysis of Pre and Post Samples on the FAAS}

An AA was used to analyse samples collected before and after electrodeposition [20].

\section{Results and Discussion}

\subsection{Effect of Voltage on the Extraction of Lead}

The results in Figure 1 show that an increase in the voltage from $4 \mathrm{~V}$ to $12 \mathrm{~V}$, resulted in an increase in weight gain. Equation (8) shows that as the voltage increases the current density increases and the resistance decreases,

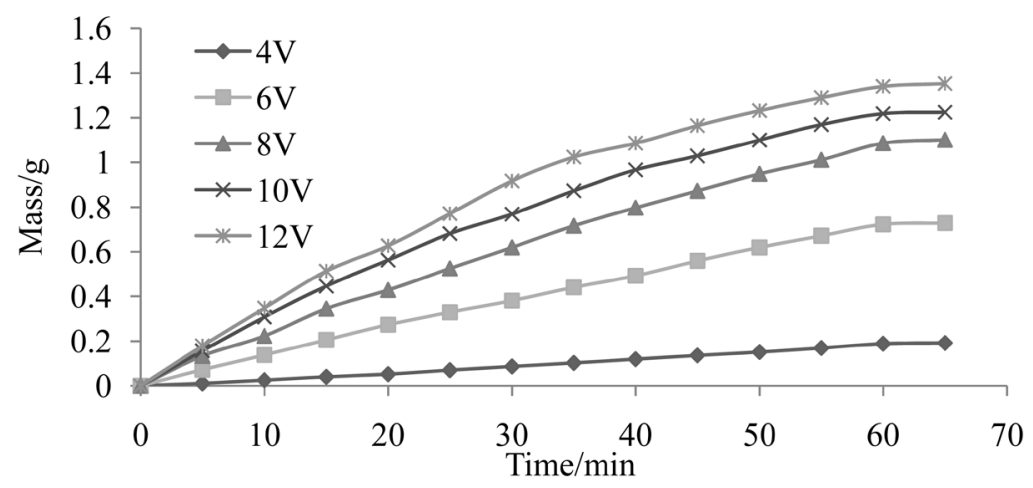

Figure 1. Mass of lead deposited with time. 
which means more metal deposition. These observations gave similar results to those of Aygar [16] who concluded that an increase in the current supplied resulted in an increase in the metal plated. Popoola et al.'s research also gave a general increase in the weight gained at the cathode as the voltage was increased from $0.5 \mathrm{~V}$ to $1 \mathrm{~V}$ [21].

As time increases the rate of lead deposited remains constant, this shows that as the film grows the film forming rate diminishes and finally trends to a limiting as was discovered by Fayomi et al. [21]. This may be due to the decrease in lead concentration in solution with increase in time and from effect of concentration it was seen that as concentration decreases the amount of metal deposited decreases. At $2 \mathrm{~V}$ there was no reaction observed. On carrying out experimental procedure at $2 \mathrm{~V}$, no significant change was observed except for the slight dissolution of the anode, which was seen to occur even in the absence of any voltage.

During electrodeposition, as time increased an increase in electrolyte temperature was observed, this seemed to lead to solution evaporation and further carbon electrode dissolution. The higher the voltage the higher the temperature increase, the higher the electrolyte volume decrease and the higher the rate of carbon electrode dissolution. This showed that during electrodeposition a small amount of heat was formed [22] and that with increase in voltage the amount of heat formed increased. Higher voltages, $8-12 \mathrm{~V}$, seemed to cause higher levels of solution heating as they experienced higher levels of solution vaporization as compared to $6 \mathrm{~V}$ and $4 \mathrm{~V}$ solutions.

Dissolution of the anode was observed; this resulted in the solution eventually turning brown black, with some of the solid settling at the bottom of the electrolytic cell which according to Lalvani [23] was to be expected. Level of dissolution seemed to increase with increase in voltage and it should be noted that an increase in voltage meant an increase in solution heating. It is concluded that as the temperature increase the rate of carbon dissolution occurred and as acetic acid is said to be corrosive it may have contributed to the dissolution. Impurities were found to inhibit electrodeposition by Mazana et al. [15].

Figure 2 shows the solution extraction efficiencies and from the graph it is noted that with increase in voltage there was a significant increase in the extraction efficiency, giving a nearly linear graph. $6 \mathrm{~V}$ seemed to have high extraction efficiency, this fact combined with the fact that at $6 \mathrm{~V}$ there was less solution heating and evaporation and less carbon dissolution, $6 \mathrm{~V}$ was concluded to be the optimum voltage.

From the observations it was concluded that a directly proportional relationship existed between the voltage and metal plated and also between the voltage and extraction efficiency with the optimum voltage being at $6 \mathrm{~V}$.

\subsection{Effect of Temperature on Lead Electrodeposition}

Figure 3 shows the graphs of metal plated with time at different temperatures. It is noted that there exists a general increase in metal plated as temperature increases, from $10^{\circ} \mathrm{C}$ to $30^{\circ} \mathrm{C}$. However, at $30^{\circ} \mathrm{C}$ it is noticeable that the level of weight gained has reduced as values are almost similar to those of metal plated at $25^{\circ} \mathrm{C}$. At $35^{\circ} \mathrm{C}$ there was a huge decrease in the level of metal plated as graph was below that of $25^{\circ} \mathrm{C}$. As temperature increased there was an increase in the level of carbon dissolution resulting in the brown humic. Levels of carbon dissolution seemed to be very high from $25^{\circ} \mathrm{C}-35^{\circ} \mathrm{C}$. With increase in temperature solution heating increased and it seemed to increase acetic acid's corrosive nature towards the carbon electrode. The existence of the humic acid in solution posed as an impurity which inhibited electrodeposition rates by increasing the resistance [15] and possibly resulting in the occurrence of side reactions [14]. As carbon dissolution increased from $25^{\circ} \mathrm{C}$ at $30^{\circ} \mathrm{C}$

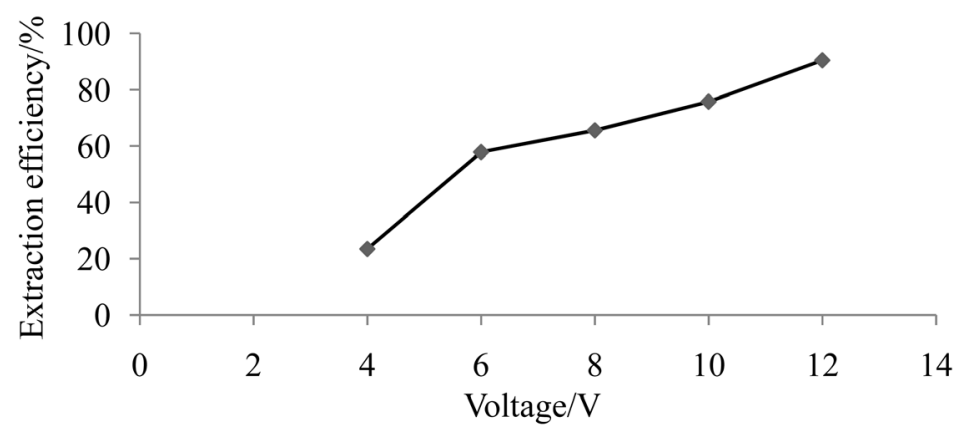

Figure 2. Lead extraction efficiencies at different voltages. 


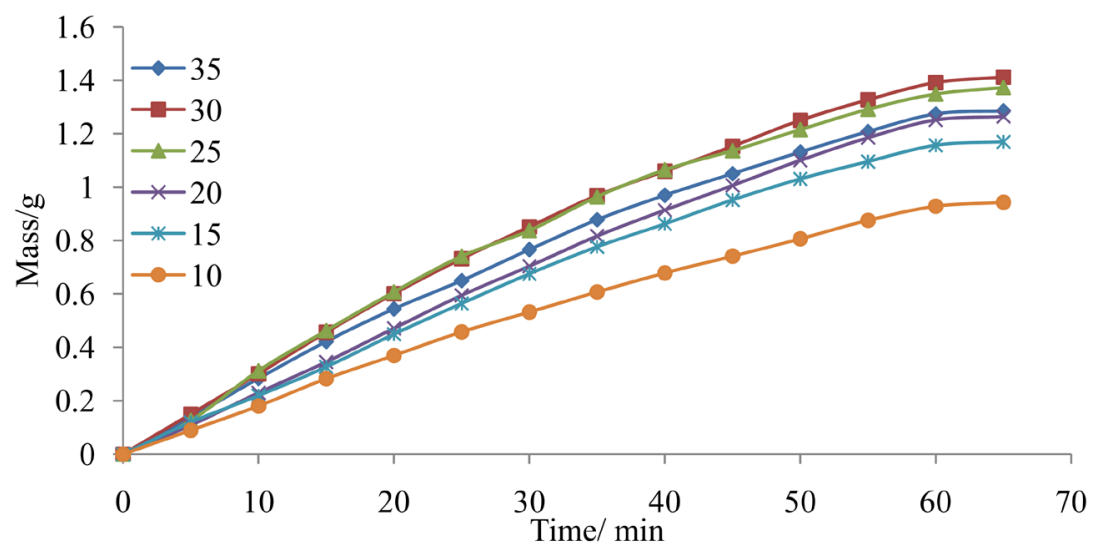

Figure 3. Mass of lead deposited with time.

and $35^{\circ} \mathrm{C}$ it had reached a point where its effects became significant enough to hinder rate of electrodeposition. The temperature during electrolysis process would cause insignificant changes due to electrode puffing [16].

The general increase in metal plated with increase in temperature was expected as it is stated that electrical efficiency increases with increase in temperature [14]. Ntengwe and coworkers observed an increase in the current density with increase in temperature from $24^{\circ} \mathrm{C}$ to $65^{\circ} \mathrm{C}$ [15]. If this is equally true for the research being carried out then with increase in temperature an increase in the metal plated was expected. Extraction efficiencies increased with temperature and became constant from $20^{\circ} \mathrm{C}-30^{\circ} \mathrm{C}$ and a sharp decrease being observed at $35^{\circ} \mathrm{C}$ (Figure 4). Extraction efficiencies of $20^{\circ} \mathrm{C}$ and $25^{\circ} \mathrm{C}$ were both at $54 \%$ with that of $30^{\circ} \mathrm{C}$ being at $53 \%$ and these were the highest extraction efficiencies experienced. There was a sharp decrease to $37 \%$ at $35^{\circ} \mathrm{C}$. This comes as no surprise as it is said that the lead electrodeposition temperature is between $20^{\circ} \mathrm{C}$ and $40^{\circ} \mathrm{C}$ [10], therefore higher electrodeposition rates are expected in this range [10].

It is then concluded that the lead leaching temperature is surely between $20^{\circ} \mathrm{C}$ and $30^{\circ} \mathrm{C}$, with the optimum temperature being chosen as $20^{\circ} \mathrm{C}$ as it is more economic, that is power saving, and gives the highest extraction efficiency $54 \%$ at a considerably average rate of metallic deposition. Studies on how temperature affects the electrodeposition process should be carried out further so as to get a more detailed explanation for the behaviors observed.

\subsection{Effect of Concentration on the Extraction of Lead from Lead Acetate}

As concentration of the solution increased the amount of lead deposited at the cathode increased, Figure 5, this was due to the fact that as concentration decreases the cell resistance increases and the current density decreased [15]. Meaning at lower concentrations, in this case $637.1 \mathrm{ppm}$ a lower rate of metallic plating was observed.

It was observed that extraction efficiencies decreased with increase in concentration (Figure 6).

Extractions were carried out for the same time lengths, therefore lower concentration had higher extraction efficiencies as the lead ratios were low compared to those of higher concentrations. Highly concentrated solutions would need more time to reach higher extraction efficiencies. Despite the higher extraction efficiencies for dilute solutions, that is $1147.1 \mathrm{ppm}$ and $637.1 \mathrm{ppm}$, higher masses of lead were extracted from solutions with higher concentrations. However, fordilute solutions several extractions need to be carried out to achieve the same results as a single extraction at higher concentration. For example at $2271 \mathrm{ppm}$ an overall of $0.5875 \mathrm{~g}$ of lead was extracted in 2 hrs and at $637.1 \mathrm{ppm}$ a mass of $0.1477 \mathrm{~g}$ was collected in the same time period. This means that roughly 4 extractions have to be conducted at $637.1 \mathrm{ppm}$ to obtain the same results as those obtained at $2271 \mathrm{ppm}$. The optimum concentration is concluded to be $2271 \mathrm{ppm}$ as it gives quicker results and is power saving and less time consuming.

\subsection{Effect of the Size of the Carbon Electrode on the Extraction of Lead}

From the electrodeposition processes it was concluded that the $0.5 \mathrm{~cm}$ radius electrode had a larger surface area as $0.3272 \mathrm{~g}$ lead was deposited in an hour and the $1 \mathrm{~cm}$ radius electrode achieved an electrodeposition of 0.2876 


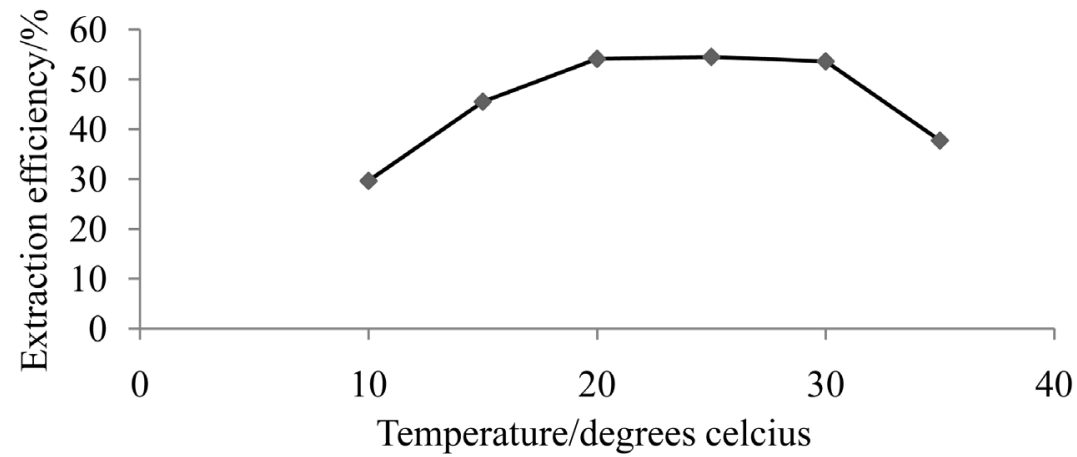

Figure 4. Effect of temperature on the extraction efficiencies.

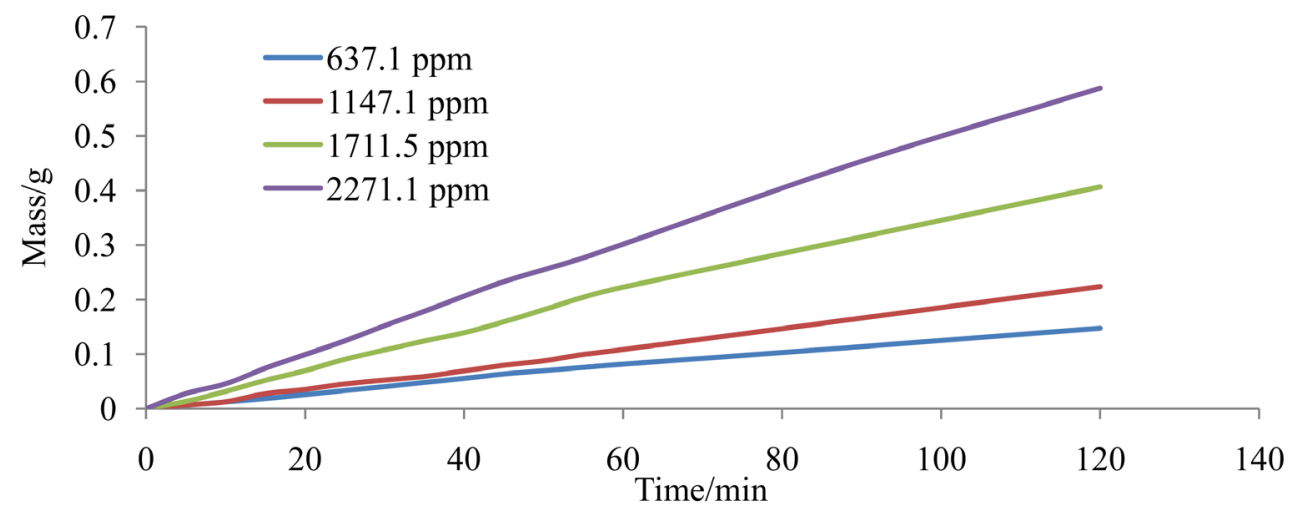

Figure 5. Mass of lead deposited with time.

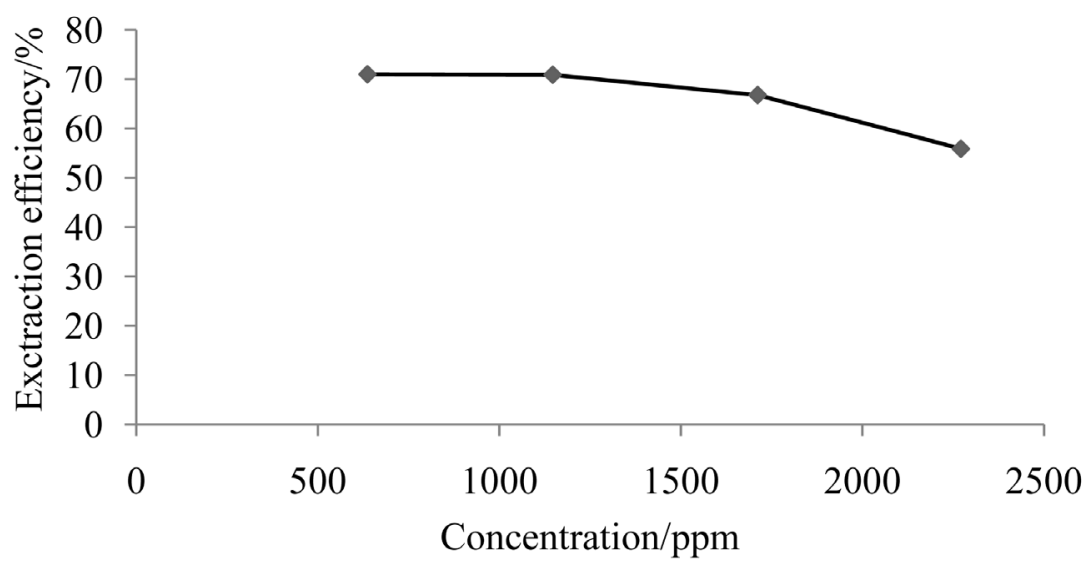

Figure 6. Effect of concentration on extraction efficiency.

g. The amount of lead deposited with time was higher for the $0.5 \mathrm{~cm}$ radius than that of the $1 \mathrm{~cm}$ radius electrode. Extraction efficiencies of 55\% and 38.6\% were achieved for 0.5 and $1 \mathrm{~cm}$ radius respectively, Figure 7 , proving that the larger the electrode surface area the larger the extraction efficiency. Electrodes with larger surface areas are said to result in a less resistive current path, therefore higher extraction efficiencies and electrodeposition rates are expected [14]. It is said that with increase in the size of the electrode there is a decrease in the current density [15], meaning the larger the electrode the lower the mass of metal deposited compared to a smaller electrode.

It was then concluded that the best electrode size was the $0.5 \mathrm{~cm}$ radius electrode. An investigation on the effect of the cathode electrode size should also be carried out. 


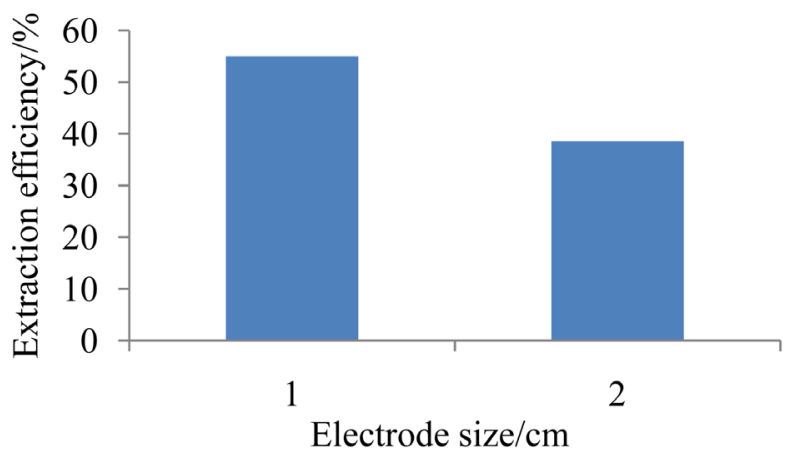

Figure 7. Effect of size of carbon electrode on extraction efficiencies.

\subsection{Effect of Distance between Anode and Cathode on the Lead Electrodeposition Process}

It was observed that as distance between electrodes increased the amount of lead deposited at the cathode decreased in a directly proportional manner, Figure 8, this was due to the decrease in the current densities. Ntengwe et al. states that as the distance between the electrodes decreases there is an increase in the current density, hence the metal deposited decreases as the distance between electrodes increases [21].

There was an increase in the extraction efficiencies from $1 \mathrm{~cm}$ distance to $4 \mathrm{~cm}$, with the $4 \mathrm{~cm}$ distance having the highest extraction efficiency of $70.9 \%$. From $4 \mathrm{~cm}$ a sharp decrease was seen giving the lowest extraction efficiency being at $20.3 \%$ for $7 \mathrm{~cm}$ electrode spacing, Figure 9 . It is said that when electrodes are placed too close to each other the value of the void fracture is increased and will result in less efficient processes [14]. When electrodes are spaced really close, there is a larger gas bubble accumulation which results in a larger electrical resistance, hence the lower extraction efficiencies. As distance between the electrodes increased, like in 3 and 4 $\mathrm{cm}$, the amount of gas bubble formation decreased and this meant lower levels of electrical resistance and hence resulted in the larger extraction efficiencies.

From the results obtained it was concluded that the optimum electrode distance was at $4 \mathrm{~cm}$ as this gave the highest extraction efficiency.

\subsection{Comparison on the Effectiveness of EDTA and Acetic Acid on Leaching and Electrodeposition}

On leaching acetic acid proved to be more effective achieving a 73.3\% extraction efficiency. EDTA achieved a $68.1 \%$ extraction. Under the same leaching conditions for acetic acid, Dondo et al., achieved $98.97 \%$ extraction efficiency [4]. $\mathrm{PbO}$ will react with acetic acid to form $\mathrm{Pb}\left(\mathrm{CH}_{3} \mathrm{COO}\right)_{2}$ [24]. Aoki et al., reported a recovery of $80 \%$ at $\mathrm{pH} 4$ after an hour of extraction [25], whereas Felix-Navarro et al., experienced a $96.8 \%$ lead recovery at $\mathrm{pH}$ 4.8 at $55^{\circ} \mathrm{C}$ with a leaching time of 30 minutes [11]. From Equation (1) it is seen that at pH 4 EDTA exists as $\mathrm{H}_{2}$ EDTA $^{2-}$, which suggests that on leaching it will form $\mathrm{PbH}_{2}$ EDTA.

Acetic acid proved to be easier to use on leaching as its process was simpler and easier. The EDTA pH needed constant monitoring to maintain it at $\mathrm{pH} 4$. Above $\mathrm{pH} 5$ extractions proved to be too low. The ability of EDTA to enhance lead solubility is said to decrease as $\mathrm{pH}$ becomes more alkaline [12] and lead is said to be more soluble under acidic conditions with an increase in temperature resulting in an increase in the amount of lead separated from the solid phase [12]. Heat was also needed with EDTA meaning more energy used. EDTA extraction took more time as 24 hrs was needed for extraction, but with acetic acid 30 minutes was enough time for high extraction levels to occur.

On electrodeposition, EDTA produced $2.0025 \mathrm{~g}$ of lead from a $7066.1 \mathrm{ppm}$ solution of lead and acetic acid had $1.7020 \mathrm{~g}$ extraction from a $6850.6 \mathrm{ppm}$ solution, (Figure 10). Electrodeposition extraction efficiencies were 95\% and $90.8 \%$ for acetic acid and EDTA respectively, showing that even though EDTA was able to extract a larger mass of metal it had a lower extraction efficiency compared to acetic acid.

Acetic acid displayed its corrosive nature by resulting in very high levels of carbon dissolution. The lead metal collected had some brown hard elements around it showing carryover of impurities from the electrolyte. EDTA on the other hand did not experience any dissolution at all. If any was experienced it was not visible. 


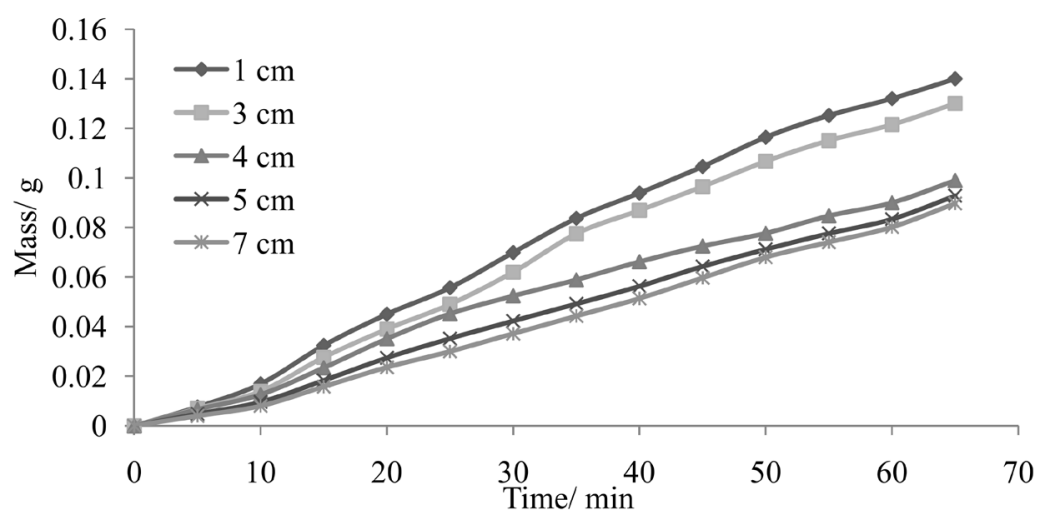

Figure 8. Mass of lead extracted with time.

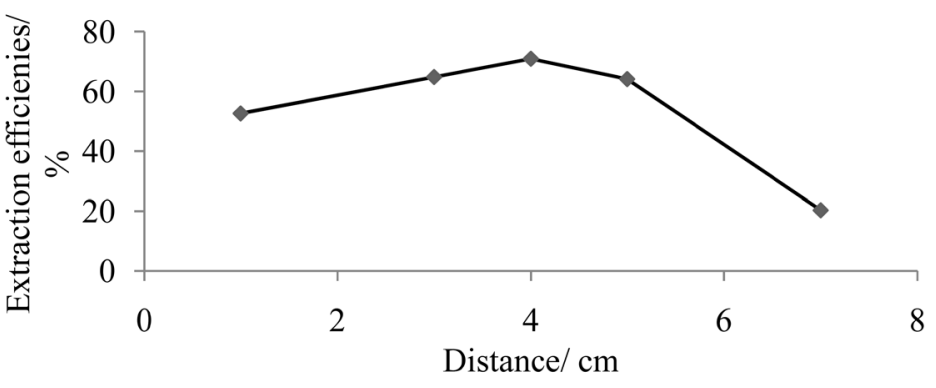

Figure 9. Effect of distance between electrodes on the extraction efficiencies.

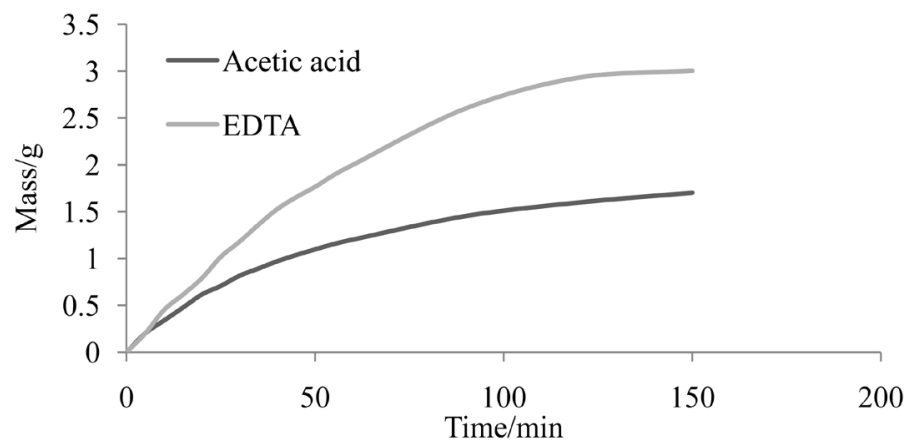

Figure 10. Mass of lead deposited with time.

It was then concluded that acetic acid was a better leachate than EDTA as it needed less energy and less monitoring. Though EDTA gave a larger amount of metal deposited and did not corrode the carbon electrode, acetic acid gave a larger extraction efficiency, 95\%, and due its cheap costs and availability it was seen to be a better electrolyte. With such results observed this lead recycling method can be made use of by mining companies. This being the case the method for lead leaching and electrodeposition needs to be compared with extractions from other solutions. This will help show how acetic acid behaves compared to other solutions.

\subsection{Cupel and Metal Analysis on the XRF}

It was seen that acetic acid produced lead metal of lower purity than EDTA and presence of sulphur was seen in the cupel and seemed to be higher in the lead extracted in both cases. The increase in sulphur content from that present in the cupel may have been due to contamination by the carbon electrode, which has been said to contain some level of sulphur [26]. The other elements detected included arsenic, manganese, cadmium among others. An investigation on the other sources of sulphur contamination in the final product should be done (Table 1). 
Table 1. Determination of elements using the XRF.

\begin{tabular}{cccc}
\hline Reading & Sulphur & Other elements & Lead \\
\hline Cupel & $17 \%$ & $38 \%$ & $45 \%$ \\
EDTA leached lead & $20 \%$ & $3 \%$ & $77 \%$ \\
Acetic acid leached lead & $28 \%$ & $6 \%$ & $66 \%$ \\
\hline
\end{tabular}

\subsection{Dissolution of Carbon Electrode}

In the presence of oxygen, high hydrogen over potential will result in some dissolution [10]. The sulphur content was seen to be higher in the lead product than the initial content in the cupel, this suggested another source of contamination. The other contamination source may be the carbon electrode as mentioned in [26], which says that sulphur ratios in carbon electrodes vary depending on the coking feed and cooking conditions.

The presence of sulphur would explain its contribution in the dissolution of the carbon electrode in acetic acid. This is said to result in electro-oxidation of the electrode giving products similar to humic acid [23]. Dissolution increased in acetic acid due to the fact that acetic acid is corrosive to carbon electrodes [18]. Since acetic acid was slightly acidic the formation of hydroxide ions during electrodeposition would have resulted in it being turned slightly alkaline. Though these were the conclusions drawn further investigations need to be carried out on the effect of acetic acid on carbon electrode dissolution. A study on the use of stabilizers that will reduce the rate of carbon dissolution by acetic acid should also be carried out.

\section{Conclusion}

The factors that affect electrodeposition of lead are voltage, temperature, concentration of lead in solution, size of electrodes and the distance between the electrodes. The lead extraction efficiency and amount of lead deposited at the cathode increased with increase in voltage. However, as voltage increases so does the rate of carbon anode dissolution. As temperature increases the amount of lead deposited increases and then starts decreasing. The optimum voltage was seen to be $6 \mathrm{~V}$, which also gave low dissolution rates and the optimum temperature was at $20^{\circ} \mathrm{C}$ with a high extraction efficiency of $54 \%$ and low carbon dissolution rate. As the lead concentration in solution increases so does the amount of lead deposited. The best operating concentration was seen to be the highest, $2271.1 \mathrm{ppm}$. The smaller the electrode radius, the larger the extraction efficiency and the amount of lead deposited, the best electrode for use was seen to be the $0.5 \mathrm{~cm}$ radius electrode. The shorter the electrode spacing the larger the amount of lead deposited. However, the moderate electrode distance, $4 \mathrm{~cm}$, in this case experiences the largest extraction efficiency. It was then concluded that the optimum electrode distance was for $4 \mathrm{~cm}$. Acetic acid gave a higher leaching efficiency (73.3\%), higher electrodeposition efficiency (95\%) with a lower amount of lead deposited with time. The lead metal produced from acetic acid electrolyte was of lower purity (66\%) than that from EDTA (77\%). Acetic acid was seen to be a better electrolyte and a better leachate than EDTA. Acetic acid proved to be corrosive as it resulted in carbon anode dissolution and EDTA did not. Components such as presence of sulphur in the carbon electrode make up and in the solution and temperature catalyzed the reaction.

\section{References}

[1] Crown (1995) Metal Manufacturing, Refining and Finishing Works, Lead Works. Department of the Environment Industry Profile, 1-3.

[2] Deng, J., Feng, Q., Wang, Y., Wen, S. and Zhao, W. (2015) Investigation of Leaching Kinetics of Cerussite in Sodium Hydroxide Solutions. Physiochemical Problems of Miral Processing, 51, 491-500.

[3] Jewell, S. (2015) Mineral Commodity Summaries 2015. In: USGS (United States Geological Survey), Virgnia, United States of America, 2015.

[4] Dondo, J., Mudzingwa, A., Muleya, E. and Mutatu, W. (2015) Recovery of Lead from Pulverised Cupels Used in Fire Assaying of Gold and Platinum Group Metals, Midlands State University, Gweru, 1-14. [Unpublished]

[5] Flynn, J. (2014) Precious Metal Analysis, Intertek Minerals. [Online]. http://www.intertek.com

[6] Minerals Services (2013) Fire Assay Gold. In: SGS Group Management, Republic of South Africa.

[7] Bugbee, E.E. (1922) A Texbook of Fire Assaying. John Wiley and Sons, New York, 89-147. 
[8] Kuipa, O., Kuipa, P.K., Mangunda, C.T. and Sithole, T.R. (2014) Recovery of Lead from Lead Laden Cupels by a Simultaneous Leaching and Electrowinning Process in a Methanesulphonic Acid Bath. International Journal of ChemTech Research, 6, 2404-2413.

[9] (2012) Zimbabwe, Chapter 16, SADC Legislation Handbook, 493-505.

[10] Paunovic, M. and Schlesingier, M. (2010) Modern Electroplating. 5th Edition, John Wiley and Sons, New York, 249263.

[11] Lin, S.W., Félix-Navarro, R.M. and Vargas-Galarza, Z. (2006) Optimizing the Conditions for Leaching Lead from Solid Waste Produced by Pyrometallurgical Process of Recycling Automobile Used Batteries. Journal of Mexican Society, 50, 64-70.

[12] Kim, C. (1996) Extraction of Lead Using EDTA: Factors Affecting Extraction, Effects of Amorphous Iron and Recycling of Used EDTA. Iowa State University, Iowa, 1-71.

[13] Gale, B.K. (n.d.). Electro Chemical Deposition: Principles, Methods and Applications. University of Utah, Utah, 1-11.

[14] Mazloomi, K., Moayedi, H. and Sulaiman, N. (2012) Electrical Efficiency of Electrolytic Hydrogen Production. International Journal of Electrochemical Science, 7, 3314-3326.

[15] Mazana, N., Ntengwe, F.W. and Samadi, F. (2010) The Effect of Impurities and Other Factors on the Current Density in Electro-Chemical Reactors. International Journal of Chemical Reactors, 2, 1289-1300.

[16] Aygar, A.M. (2009) Investigation on the Factors That Affect the Amount of Metal Coated in an Electroplating Process. $1-20$.

[17] Shakhashiri, P. (2008) Acetic Acid and Acetic Anhydride. Journal of General Chemistry, 2-3. http://www.scifun.org

[18] Mukherjee, A.K. and Singh, S.K. (2010) Kinetics of Mild Steel Corrosion in Aqueous Acetic Acid Solutions. Journal of Materials Science Technology, 26, 264-269. http://dx.doi.org/10.1016/S1005-0302(10)60044-8

[19] Aoki, K., Niinae, M. and Nishigaki, K. (2008) Removal of Lead from Contaminated Soils with Chelating Agents. Journal of Materials Transactions, 49, 2377-2382. http://dx.doi.org/10.2320/matertrans.M-MRA2008825

[20] Gupta, P.K., Singh, K., Singh. N., Singh, N.S., Soni, D. and Tripathy, S.S. (2013) Evaluation of Purity with Its Uncertainty Value in High Purity Lead Stick by Conventional and Electro-Gravimetric Methods. Journal of Chemistry Central, 2013, Article ID: 745101. http://dx.doi.org/10.1155/2013/745101

[21] Fayomi, O.S.I. and Popoola, A.P.I. (2011) Effect of Some Process Variables on Zinc Coated Low Carbon Steel Substrates. Scientific Research and Essays, 6, 4264-4272. http://dx.doi.org/10.5897/SRE11.777

[22] Nandi, P. (2013) Effect of Alternating Current on Electrolytic Solutions. IOSR Journal of Engineering, 3, 51-59. http://dx.doi.org/10.9790/3021-03825259

[23] Lalvani, S.B. (2012) Investigations of Anodically Oxidised Coal. Southern Illinois University Carbondale, Carbondale, 107-117.

[24] Adriaens, A. and Schotte, B. (n.d.) Stabilization of Corroded Lead Artefacts in Museums: Insights into the Effects of Electrolytic Reduction as a Treatment. Journal of Analytical Chemistry, 1-18.

[25] The Nuffield Foundation (2008) Extracting and Purifying Metals. Journal of Advanced Applied Science, 1-22.

[26] Radenovic, A. (2012) Properties of Carbon anode Components for Aluminium Production. North American Free Trade Agreement, 63, 111-114.

\section{Submit or recommend next manuscript to OALib Journal and we will provide best service for you:}

- Publication frequency: Monthly

- 9 subject areas of science, technology and medicine

- Fair and rigorous peer-review system

- Fast publication process

- Article promotion in various social networking sites (LinkedIn, Facebook, Twitter, etc.)

- Maximum dissemination of your research work

Submit Your Paper Online: Click Here to Submit

Contact Us: service@oalib.com 